\title{
Pannexin-1 in Human Lymphatic Endothelial Cells Regulates Lymphangiogenesis
}

\author{
Jonathan Boucher ${ }^{1}$, Claire Simonneau ${ }^{1}$, Golthlay Denet ${ }^{1}$, Jonathan Clarhaut ${ }^{2,3}$, \\ Annie-Claire Balandre ${ }^{1}$, Marc Mesnil ${ }^{1}$, Laurent Cronier ${ }^{1}$ (D) and Arnaud Monvoisin ${ }^{1, *}$ \\ 1 CNRS ERL 7003, Laboratoire "Signalisation \& Transports Ioniques Membranaires", University of Poitiers, \\ 86073 Poitiers, France; jonathan.boucher@univ-poitiers.fr (J.B.); claire.simonneau86@gmail.com (C.S.); \\ golthlay.denet@etu.univ-poitiers.fr (G.D.); annie-claire.balandre@univ-poitiers.fr (A.-C.B.); \\ marc.mesnil@univ-poitiers.fr (M.M.); Laurent.Cronier@univ-poitiers.fr (L.C.) \\ 2 CNRS UMR 7285, Institut de Chimie des Milieux et des Matériaux de Poitiers (IC2MP), \\ University of Poitiers, 86073 Poitiers, France; jonathan.clarhaut@chu-poitiers.fr \\ 3 CHU de Poitiers, 86021 Poitiers, France \\ * Correspondence: arnaud.monvoisin@univ-poitiers.fr; Tel.: +33-054-936-6385
}

Received: 27 April 2018; Accepted: 22 May 2018; Published: 24 May 2018

\begin{abstract}
The molecular mechanisms governing the formation of lymphatic vasculature are not yet well understood. Pannexins are transmembrane proteins that form channels which allow for diffusion of ions and small molecules $(<1 \mathrm{kDa})$ between the extracellular space and the cytosol. The expression and function of pannexins in blood vessels have been studied in the last few decades. Meanwhile, no studies have been conducted to evaluate the role of pannexins during human lymphatic vessel formation. Here we show, using primary human dermal lymphatic endothelial cells (HDLECs), pharmacological tools (probenecid, Brilliant Blue FCF, mimetic peptides $\left[{ }^{10} \mathrm{Panx}\right]$ ) and siRNA-mediated knockdown that Pannexin-1 is necessary for capillary tube formation on Matrigel and for VEGF-C-induced invasion. These results newly identify Pannexin-1 as a protein highly expressed in HDLECs and its requirement during in vitro lymphangiogenesis.
\end{abstract}

Keywords: lymphatic endothelial cells; pannexins; Panx1; lymphangiogenesis; cell invasion; Vascular Endothelial Growth Factor-C (VEGF-C)

\section{Introduction}

Pannexin-1 (PANX1) is one of the three members of the Pannexin family with PANX2 and PANX3 discovered through homology to the invertebrate gap-junction forming proteins, innexins [1,2]. Pannexins (PANXs) and Connexins (CXs) share similar protein structure while they lack amino acid sequence homology [3]. By hexameric oligomerization PANX1 forms unopposed large-pore channels $[4,5]$ which allow the release of molecules up to $1 \mathrm{kDa}$ into the extracellular space such as ions, adenosine triphosphate (ATP) and other nucleotides [6,7]. PANX1 is ubiquitously expressed in several organs and tissues [2,8-12] and is the best characterized isoform of the PANX family. For a long time, PANX2 expression has been restricted to the central nervous system [13], but it is now well described that PANX2 is also ubiquitously distributed throughout the body [14]. Similarly, PANX3 has been mainly described in cartilage, bone and skin [2,11,15-21] but accumulating evidences show PANX3 expression in other tissues such as skeletal muscle, heart, cochlea, and arteries $[2,15,18,22,23]$.

In line with the large PANX1 tissue distribution, this ATP release channel is directly or indirectly involved in numerous physiological functions or pathologies such as inflammatory diseases [24] or cancer $[25,26]$. However, little is currently known regarding the role of PANX1 in the vasculature. PANX1 has been found to be expressed in vivo within the vascular wall in arteries, arterioles, capillaries, 
veinules and smooth muscle cells (SMCs) but not in veins [12,27] and in vitro in isolated blood endothelial cells (ECs) [28-30]. Panx1-deficient mice showed significantly impaired endothelial function [31]. ATP release via PANX1 channels by either ECs or SMCs has been involved in the regulation of vascular tone, inflammation, and cerebral ischemic stroke [30,32,33]. While many data are available in blood vascular system, studies regarding roles of Panxs in regulating lymphatic vascular development are currently missing [34]. The main role of the lymphatic system is to transport in a unidirectional way extravasated fluids and macromolecules from tissues, through lymph nodes, back to the blood circulation to maintain homeostasis [35]. Lymphangiogenesis, the formation of new lymphatic vessels from preexisting ones [36,37], is associated with several diseases such as chronic inflammation, graft rejection and metastatic dissemination [38]. Since the identification of the Vascular Endothelial Growth Factor-C (VEGF-C) as the major lymphangiogenic factor [39], several other key genes and proteins involved in lymphatic development have been identified. Among them, it has recently been shown that at least three CX isoforms (CX37, CX43 and CX47) are expressed in developing and mature lymphatic vessels [40-42]. These studies showed that these CXs are necessary for the proper lymphatic valve development in collecting vessels and contribute to morphogenesis of the jugular lymph sac and thoracic duct. Moreover, CX mutations or deficiency in mouse and humans have been found to lead to lymphedema $[40,43,44]$. Regarding PANXs, no in vitro nor in vivo data were available onto their expression and/or function in human lymphatic vasculature and only one recent study has shown the expression of Panx1 in mouse LECs by qPCR [45]. This study aims to investigate the expression of PANXs in human lymphatic endothelial cells and more particularly the role of PANX1 during lymphangiogenesis.

\section{Results}

\subsection{Human Lymphatic Endothelial Cells Express Pannexins}

PANX1, -2 and -3 mRNA expression was examined by quantitative RT-PCR in human lymphatic endothelial cells. As shown in Figure 1A, the expression of PANX1 was highest among the 3 PANX gene family while PANX2 and PANX3 were barely expressed.

Interestingly, Western blot analysis demonstrated that all three PANX isoforms were expressed in the HDLECs (Figure 1B). All PANXs were detected at the expected molecular weight. As previously described, a specific banding pattern of three bands was revealed for PANX1 indicating three different glycosylation states: Gly0, non-glycosylated core protein; Gly1, high-mannose species and Gly2, complex glycosylated species $[4,46]$.

Confocal imaging of HDLECs showed a clear localization of PANX1 to the plasma membrane and in the perinuclear compartment (Figure 1C). Importantly, we found that VEGF-C, the main regulator of lymphangiogenesis, increased PANX1 expression in HDLECs after 6 and $24 \mathrm{~h}$ treatment by $78 \pm 5 \%$ and $70 \pm 5 \%$, respectively (Figure 1D,E) whereas PANX2 and PANX3 expressions remained unaffected (Figure S1). Taken together, these results show that PANXs are expressed in HDLECs. Since PANX1 is the prevalent isoform and its expression is specifically modulated by VEGF-C, PANX1 is likely to be involved in lymphatic function. 


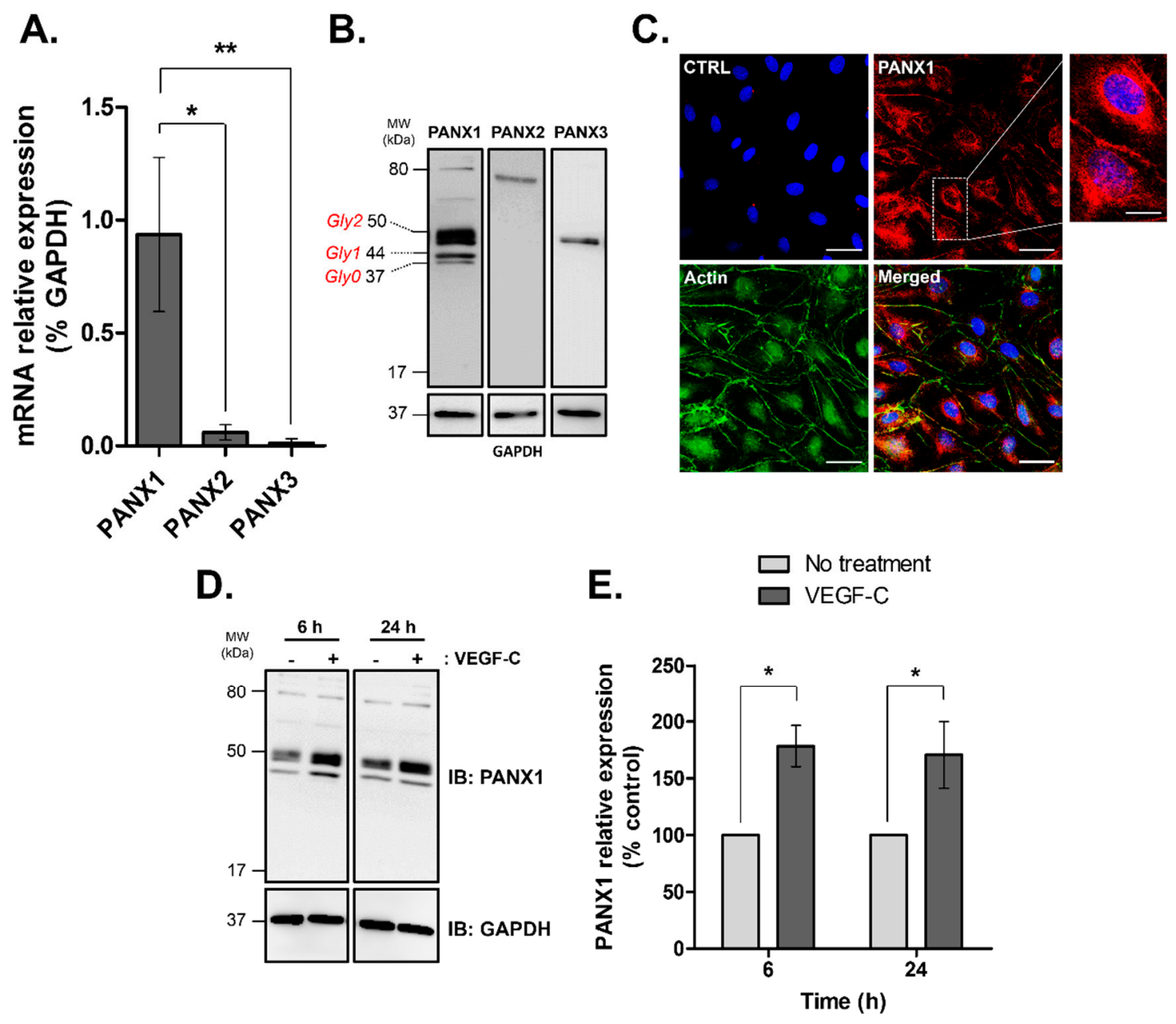

Figure 1. Pannexin isoforms expression in human dermal lymphatic endothelial cells (HDLECs). (A) PANXs mRNA expression in isolated HDLECs quantified by RT-PCR and normalized by GAPDH. The data represent mean \pm SD from three independent experiments; (B) Western blot analysis of total protein extracts $(20 \mu \mathrm{g} /$ lane) from four independent HDLEC cultures demonstrating PANXs expression in HDLECs. Unglycosylated (Gly0) and glycosylated isoforms (Gly1 and Gly2) of PANX1 are indicated; (C) PANX1 immunofluorescence in HDLECs (red), F-actin was FITC-phalloidin stained (green) and nuclei were DAPI-stained (blue). CTRL: control immunofluorescence after omission of the primary antibody, Scale bar: $50 \mu \mathrm{m}$; Enlarged image marked by the white box shows higher magnification of PANX1 staining, scale bar $7 \mu \mathrm{m}$; (D) Representative Western blot analysis and (E) densitometric quantification of PANX1 expression normalized to GAPDH following $100 \mathrm{ng} / \mathrm{mL}$ VEGF-C treatment for the indicated times in HDLECs. Values are expressed as mean \pm SD from three independent experiments. ${ }^{*} p<0.05$ and ${ }^{* *} p<0.01$.

\subsection{Pharmacological Inhibitors of Pannexin-1 Modulate In Vitro Lymphangiogenesis}

To investigate whether PANX1 might be involved in lymphangiogenesis we used the in vitro tube-formation assay which is a well-established test based on the ability of LECs to form three-dimensional capillary-like network when seeded on basement membrane extracts (Figure 2A, untreated). Treatment of HDLECs with Probenecid or Brilliant Blue FCF resulted in a disorganized tubular network (Figure 2A). Tube length complexes were significantly inhibited by $28 \pm 4 \%$ and $20 \pm 3 \%$ with probenecid at 0.1 and $1 \mathrm{mM}$ respectively and inhibited by $21 \pm 3 \%$ and $29 \pm 4 \%$ with Brilliant Blue FCF at 1 and $5 \mu \mathrm{M}$ respectively (Figure 2B). Number of junctions were also significantly 
inhibited by $28 \pm 4 \%$ and $22 \pm 3 \%$ with probenecid at 0.1 and $1 \mathrm{mM}$ respectively and inhibited by $25 \pm 4 \%$ and $33 \pm 6 \%$ with Brilliant Blue FCF at 1 and $5 \mu \mathrm{M}$, respectively (Figure 2B).

A.

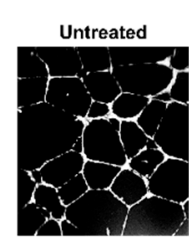

Untreated

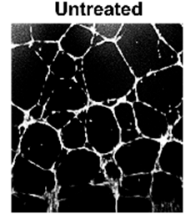

Untreated

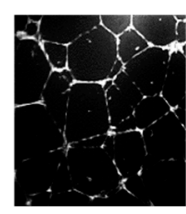

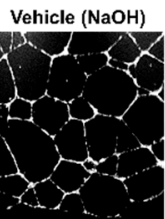

BBFCF $(1 \mu \mathrm{M})$

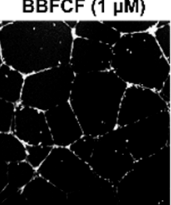
$\underset{(50 \mu \mathrm{M})}{\text { Scrambled peptide }}$

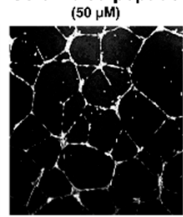

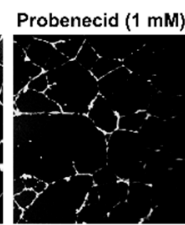

BBFCF $(5 \mu \mathrm{M})$

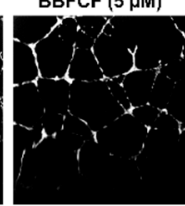

${ }^{10} \mathrm{Panx}$
$(50 \mu \mathrm{M})$

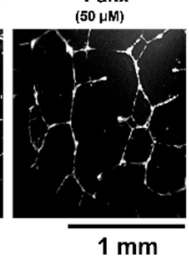

B.
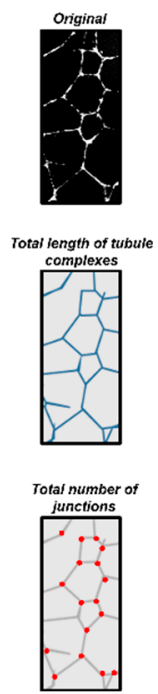
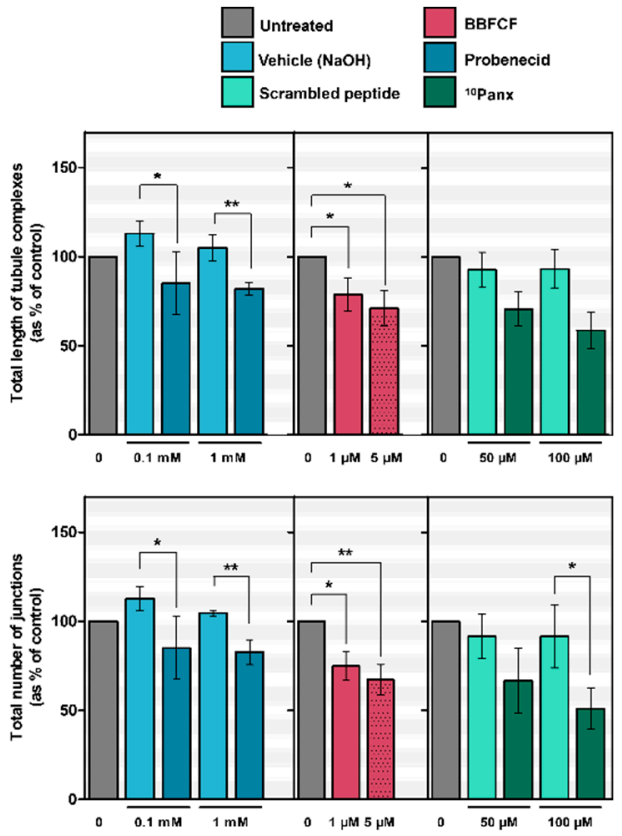

Figure 2. Inhibition of capillary-like formation in HDLECs by pharmacological inhibitors of Pannexin-1. (A) Representative images of capillary network formation by HDLECs seeded on Matrigel and treated with Probenecid, Brilliant Blue FCF or mimetic peptide ${ }^{10}$ Panx; (B) Quantitative analysis for total length of tubule complexes and for total number of junctions in control and treated HDLECs. Data represent the mean \pm SD from three independent experiments conducted in triplicate. ${ }^{*} p<0.05$ and ** $p<0.01$.

The implication of PANX1 in this process was confirmed by a second set of experiments using the mimetic inhibitory peptide ${ }^{10} \mathrm{Panx}$ instead. Results showed that the lengths of the capillary-like complexes and number of junctions in the HDLECs treated with ${ }^{10} \mathrm{Panx}$ at 50 or $100 \mu \mathrm{M}$ were respectively $22 \pm 2 \%$ or $34 \pm 3 \%$ shorter and $25 \pm 2 \%$ or $40 \pm 4 \%$ lower than those observed in the control group (Figure 2B).

\subsection{Pannexin-1 Silencing Inhibits In Vitro Lymphangiogenesis}

To confirm the role of PANX1, we decided to inhibit its expression in HDLECs by siRNA silencing. Figure 3A shows that the siRNA significantly inhibited by $80 \pm 11 \%$ the expression of PANX1 $24 \mathrm{~h}$ after transfection compared to scramble. We observed no compensation by PANX2 nor PANX3 expression after PANX1 silencing (Figure 3B). Using the tube formation assay, PANX1 siRNA-transfected HDLECs showed less extensive capillary formation compared to control (Figure 3C). Once again, quantitative analyses showed that the total length of tubule complexes and the number of junctions formed by HDLECs were significantly inhibited by $24 \pm 4 \%$ and $34 \pm 3 \%$ respectively when PANX1 was silenced as compared with control (Figure 3D). 

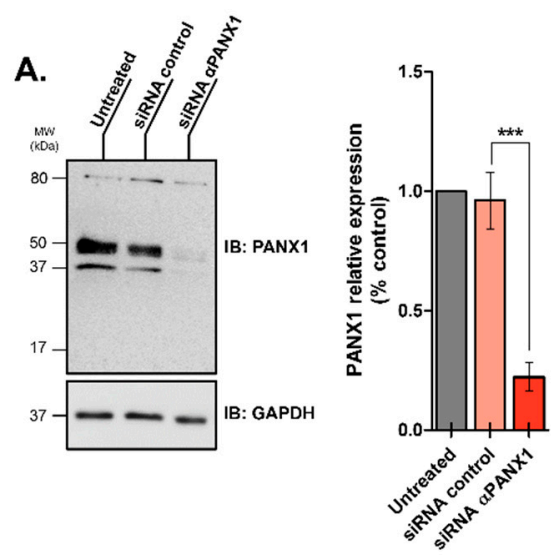

C.
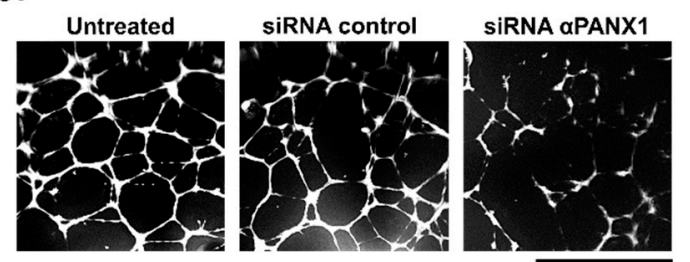

$1 \mathrm{~mm}$
B.
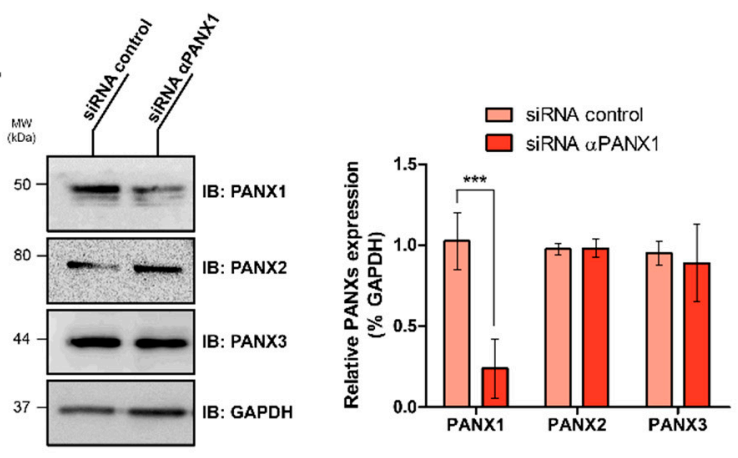

D.
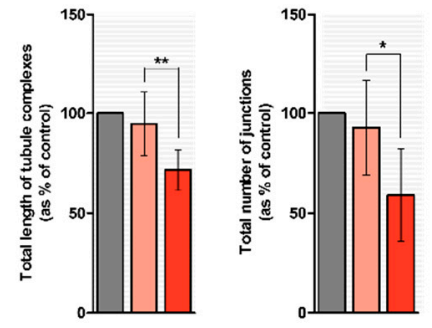

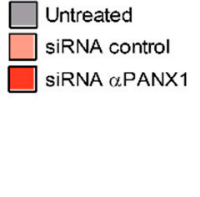

Figure 3. Silencing Pannexin-1 expression affects capillary-like formation by HDLECs. (A) Representative immunoblots of HDLECs extracts prepared $48 \mathrm{~h}$ after transfection with either the control or the PANX1-specific siRNAs. GAPDH blot served as the loading control; Bar graph shows the quantification of PANX1 expression loss $48 \mathrm{~h}$ after siRNA transfection. Data represent the mean $\pm \mathrm{SD}$ from four independent experiments; (B) Representative immunoblots and densitometric quantification of PANX1, PANX2 and PANX3 expression from HDLECs extracts prepared $48 \mathrm{~h}$ after transfection with either the control or the PANX1-specific siRNAs. GAPDH blot served as the loading control; (C) Representative images of tube structure formation in HDLECs on Matrigel after transfection. Cells transfected with PANX1 siRNAs showed defects in capillary network formation; (D) Quantitative analysis for total length of tubule complexes and total number of junctions per field in control and PANX1 siRNA-transfected HDLECs. Data represent the mean \pm SD from six independent experiments conducted in duplicate. ${ }^{*} p<0.05,{ }^{* *} p<0.01$ and ${ }^{* * *} p<0.001$.

\subsection{Pannexin-1 Silencing Inhibits In Vitro HDLECs Invasion but Not Cell Proliferation}

To investigate if PANX1 deficiency in HDLECs affected lymphangiogenesis by modulating cell proliferation, we used the BrdU incorporation assay. The results showed that knockdown of PANX1 had no effect on HDLECs proliferation when LECs were grown in EGM-V2 media (Figure 4A).

Finally, we tested the hypothesis that PANX1 is important for HDLECs invasion and we examined whether invasion of HDLECs induced by VEGF-C is affected by loss of PANX1 using a modified Boyden chamber assay. Figure $4 \mathrm{~B}$ shows the results of a typical invasion experiment. The quantification revealed a significant inhibition of HDLECs invasion by $59 \pm 6 \%$ after PANX1 expression silencing compared to scramble (Figure 4C) that can explain the disorganized capillary network we observed previously. 
A.

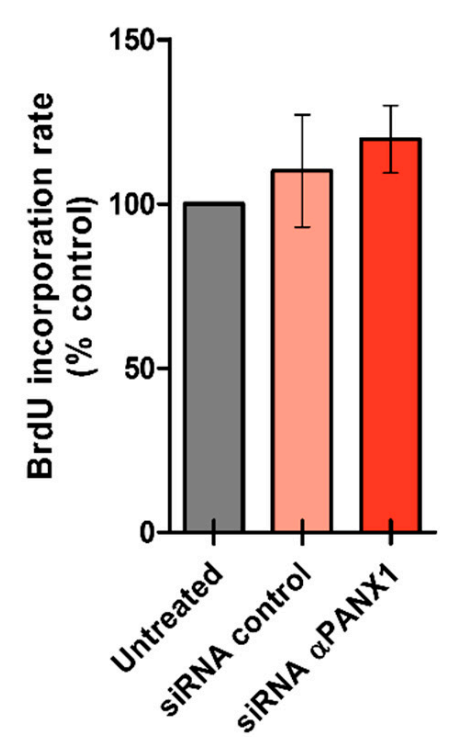

B.

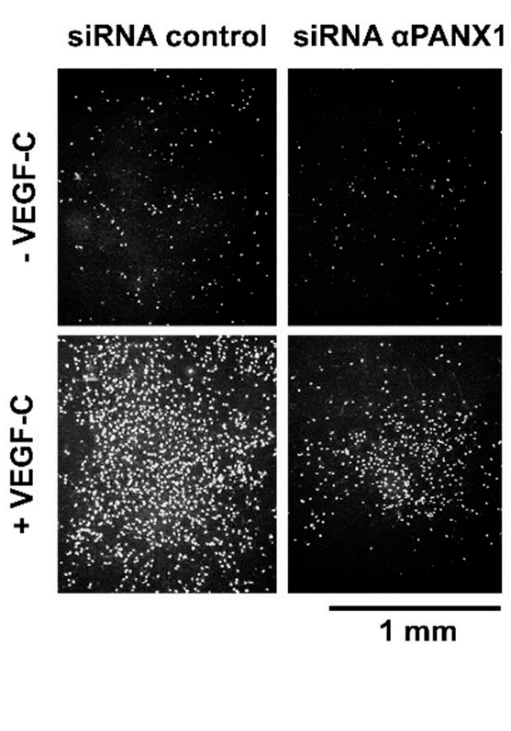

c.

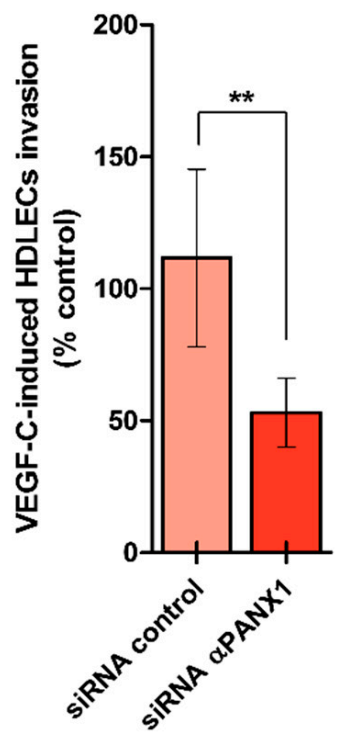

Figure 4. Loss of Pannexin-1 inhibits VEGF-C-mediated invasion of HDLECs. (A) HDLECs proliferation measurement $48 \mathrm{~h}$ after transfection with either control of PANX1 siRNAs in EGM-V2 media. Data represent the mean from three independent experiments conducted in triplicate (B) HDLECs were transfected with either control or PANX1 siRNAs and subjected to Boyden chamber assays in the presence or absence of VEGF-C $(100 \mathrm{ng} / \mathrm{mL})$. Representative images of HDLECs that invaded and migrated through the membrane pores after $18 \mathrm{~h}$ are shown; (C) Bar graph represents the mean number of invading cells. Results are expressed as the mean \pm SD of three independent experiments conducted in triplicate. ${ }^{* *} p<0.01$.

\section{Discussion}

In this present work, we tested the hypothesis that Pannexin-1 is important for human lymphatic endothelial cells to form capillary-like structures for extracellular matrix (ECM)-induced morphogenesis.

We expected PANX1 to be present in human LECs because it is ubiquitously expressed in vivo [2], in several cell lines [47], in human venous ECs [29,30,48] which share a common origin with LECs [36,37] and in murine LECs [45]. Indeed, by quantitative RT-PCR, we found that PANX1 was the most expressed member of the pannexin family in HDLECs. We also observed weak mRNA expression of PANX2 and PANX3 which could confirm their wider expressions in the human body as demonstrated by previous studies $[14,15,18,22,23]$. Additional work will be required to define the possible role of PANX2 and PANX3 in lymphatic development especially in pathological situations, since no major lymphatic phenotypic abnormalities are observed in adult mice deficient for these PANXs [19,20,32].

Our study reveals that PANX1 exhibited diverse localization patterns in HDLECs. As expected, based on its channel-forming ability, PANX1 localized at the plasma membrane [49,50]. PANX1 has also been found in the perinuclear compartment which has already been observed with endogenous PANX1 in other primary cell cultures or cell lines such as osteoblasts [49] or astrocytes and neurons [51-53]. Interestingly, when PANX1 was transfected into human bone marrow ECs, PANX1 localized in the endoplasmic reticulum (ER) and Golgi apparatus [8] and this pattern was observed in vivo in blood ECs of the lens [9]. It is well documented that this pattern reflects the intracellular PANX1 trafficking during which PANX1, as an unglycosylated core (Gly0), is glycosylated in the ER to a high-mannose form (Gly1), and then, in the Golgi to a complex glycosylated form (Gly2), before reaching the plasma membrane $[4,46,54]$. Our Western blot analysis obtained from HDLECs lysates revealed these multiple 
species of PANX1 which correlate with PANX1 distribution observed in HDLECs. Another possibility to explain this intracellular localization is that PANX1 may form $\mathrm{Ca}^{2+}$-permeable channels in the endoplasmic reticulum as observed in prostate cancer cells [55].

There is then no clear evidence that PANX1 might be essential for proper lymphatic vasculature development. Indeed, neither the Panx1-deficient mice [56,57] nor the only first patient with a PANX1 homozygous germline variant [58] display obvious phenotypes such as lymphedema that would suggest alteration in lymphatic vasculature function. Recently, Molica et al. showed, using double knock-out mice for Panx1 and Apoliprotein E (Apoe) to evaluate Panx1 role in atherosclerosis, that Panx1 in this context is necessary for lymphatic function by contributing to the drainage of interstitial fluid and to the uptake of dietary fat from the gut [47]. Nevertheless, in this study, there was no detail regarding density and morphology of the lymphatic vasculature in this Panx1-/-ApoE-/mice as for the other Panx1-deficient models. In this present study, using three different strategies to inhibit PANX1, we find that this pannexin is required for in vitro lymphangiogenesis. In addition, we did not observe compensation by PANX2 or PANX3, in PANX1 siRNA-treated HDLECs that failed to form in vitro a well-organized capillaries network. Given the apparent normal lymphatic development in Panx1-deficient mice, it is possible that compensation by Panx2 or/and Panx3 arises in vivo in LECs. This has been observed in muscle [23] and arteries [59] where Panx1 deletion caused an increase in Panx3 expression which can also act as an ATP-release channel [60]. Additional work using Panx1-deficent mice to study the expression of all the members of the pannexin family in the lymphatic vasculature and in isolated LECs will be required to answer this question.

Lymphangiogenesis is a multistep process in which the proliferation and invasion abilities of LECs play a fundamental role. Depending on the cell types, PANX1 may promote [61], decrease [11,62] or have no effect on proliferation [23]. Our work shows that PANX1 knockdown did not change the proliferative rate of HDLECs, which suggests that the inhibition of the in vitro lymphangiogenesis that we observed is not due to an inhibitory effect on the cell cycle. Finally, we focused our work on the role of PANX1 in invasion which is a process that combines both ECM degradation and cell migration. We found out that PANX1, which was up-regulated in HDLECs by VEGF-C, is necessary for the VEGF-C-mediated invasion of HDLECs. Since PANX1 was found at the plasma membrane of HDLECs, it is reasonable to speculate that PANX1 acts as an ATP-release channel to explain its role during this step. We hypothesize that the release of ATP modulates LECs function such as migration through the activation of purinergic receptors as shown for other cell types $[63,64]$. Once bound to these receptors, ATP might induce $\mathrm{Ca}^{2+}$ release from intracellular $\mathrm{Ca}^{2+}$ stores, a signaling pathway that has been implicated in LECs migration and lymphangiogenesis [65,66]. LECs are known to express four P2 purinergic receptors (P2RX4, P2RX7, P2RY1 and P2RY11) with high expression of P2RX4 and P2RY1, and interestingly, inhibition of P2RY1 in presence of a specific antagonist impaired ATP-induced migration of HDLECs [67].

Meanwhile, we cannot exclude the hypothesis that PANX1 has channel-independent roles in regulating in vitro lymphangiogenesis. PANX1 directly interacts with the cytoskeleton through its association with actin and Arp2/3 and this association has been shown to modulate cell behavior $[50,68,69]$. Detailed molecular mechanism of PANX1-driven lymphangiogenesis is still unclear. Future studies using mouse model with lymphatic-specific deletion of PANX1, PANX2 or PANX3 will clarify their relative roles during developmental and pathological lymphangiogenesis.

\section{Materials and Methods}

\subsection{Antibodies and Reagents}

Rabbit polyclonal antibody against PANX1 was purchased from Sigma (HPA016930, St. Louis, MO, USA). Rabbit polyclonal anti-PANX2 was purchased from Santa Cruz Biotechnology (sc-133880, Santa Cruz, CA, USA). Mouse monoclonal anti-PANX3 was from R\&D Systems (MAB8169, Minneapolis, MN, USA). Mouse monoclonal anti-GAPDH antibody (5G4) was supplied by HyTest 
(Turku, Finland). Goat polyclonal HRP-conjugated secondary antibodies anti-Mouse and anti-Rabbit were from Agilent Dako (P044701-2, Santa Clara, CA, USA) and Sigma (A0545), respectively. Goat polyclonal Alexa Fluor 568-conjugated antibodies (anti-Mouse) were purchased from Molecular Probes, Thermo Fisher Scientific (A-11011, Waltham, MA, USA). FITC-Phalloidin (F432) and DAPI (D3571) were from Molecular Probes, Thermo Fisher Scientific. Calcein-AM was purchased from Sigma (C1359). Silencer Pre-designed siRNA against PANX1 (134470) and Silencer Select negative control siRNA (4390843) were obtained from Ambion, Thermo Fisher Scientific. Matrige ${ }^{\circledR}$ matrix was obtained from Corning (354234, Corning, NY, USA). Recombinant Human Vascular Endothelial Growth Factor-C (VEGF-C) was obtained from Immunotools (11344692, Friesoythe, Germany) and reconstituted as a $100 \mu \mathrm{g} / \mathrm{mL}$ solution in sterile water. Probenecid (P8761) and Brilliant Blue FCF (80717) were purchased from Sigma and reconstituted as $50 \mathrm{mg} / \mathrm{mL}$ solution in $1 \mathrm{M} \mathrm{NaOH}$ and as $30 \mathrm{mg} / \mathrm{mL}$ solution in sterile water, respectively. ${ }^{10}$ Panx mimetic peptide (Trp-Arg-Gln-Ala-Ala-Phe-Val-Asp-Ser-Tyr) and Scrambled ${ }^{10}$ Panx control peptide (Phe-Ser-Val-Tyr-Trp-Ala-Gln-Ala-Asp-Arg) were from Tocris Bioscience (Bristol, UK) and reconstituted as $0.5 \mathrm{mg} / \mathrm{mL}$ solution in PBS or water, respectively.

\subsection{Cell Culture}

Primary human dermal lymphatic endothelial cells (HDLECs) were obtained from Promocell (Heidelberg, Germany) and grown in EGM-V2 media which consists of EBM-2 basal media supplemented with 5\% FCS and defined supplements such as epidermal growth factor (EGF), basic fibroblast growth factor (bFGF), insulin-like growth factor 1 (long R3 IGF-1), vascular endothelial growth factor A (VEGF-A), ascorbic acid and hydrocortisone. When HDLECs reached $80 \%$ confluency, cells were trypsinized following the procedure recommended by Promocell and then plated at $1 \times 10^{3}$ cells $/ \mathrm{cm}^{2}$. HDLECs were used up to passages $6-8$ for all experiments.

\subsection{Quantitative Real-Time PCR Analysis}

$1 \times 10^{5}$ HDLECs in $2 \mathrm{~mL}$ EGM-V2 medium were seeded in six-well plates and $24 \mathrm{~h}$ after, total RNA was extracted using the NucleoSpin RNA XS kit (Macherey-Nagel, Düren, Germany). Reverse transcription was performed with SuperScript II (Invitrogen, Thermo Fisher Scientific, Waltham, MA, USA) from $2 \mu \mathrm{g}$ of total RNA according to the manufacturer's instructions. Gene expression was assessed relative to GAPDH by quantitative PCR with the GeneAmp 7000 Sequence Detection System and SYBR Green chemistry (Applied Biosystems, Thermo Fisher Scientific). Human GAPDH, PANX1, PANX2 and PANX3 primer sequences are listed in Table S1. Sensitivity and specificity of each primer couple were checked. For each primers, qPCR was also performed with plasmids containing the cDNA of PANX1, PANX2 and PANX3, serving as positive controls.

\subsection{Western Blot}

$1 \times 10^{5}$ HDLECs in $2 \mathrm{~mL}$ EGM-V2 medium were seeded in six-well plates. $24 \mathrm{~h}$ after, cells were lysed with $30 \mu \mathrm{L}$ extraction buffer $(150 \mathrm{mM} \mathrm{NaCl}, 10 \mathrm{mM}$ Tris-HCl, pH 8.0, $1 \mathrm{mM}$ EDTA, 1 mM EGTA, 1\% Triton X-100, 0.5\% NP-40, 100 mM sodium orthovanadate) completed with $1 \times$ protease inhibitors cocktail (Roche Applied Science, Penzberg, Germany). Protein concentration was measured using DC protein assay kit (Bio-Rad Laboratories, Hercules, CA, USA). Afterwards $20 \mu \mathrm{g}$ total proteins samples were mixed with an equal volume of 5X SDS gel-loading buffer $(150 \mathrm{mM}$ Tris-HCl, pH 6.8, 5\% SDS, 12.5\% 2-mercaptoethanol, 25\% glycerol and 0.025\% bromophenol blue). Proteins were resolved using 10\% SDS-PAGE gels and transferred to PVDF membranes (Merck Millipore, Darmstadt, Germany). Membranes were blocked with 5\% non-fat powdered milk in Tris-buffered saline-Tween (TBS-T; $25 \mathrm{mM}$ Tris-HCl, pH 8.0, $15 \mathrm{mM} \mathrm{NaCl}, 0.01 \%$ Tween 20) for $3 \mathrm{~h}$ and incubated overnight at $4{ }^{\circ} \mathrm{C}$ with primary antibodies (anti-PANX1, 1:800; anti-PANX2, 1:350; anti-PANX3, 1:1000). Membranes were then washed with TBS-T and incubated with corresponding secondary horseradish peroxidase-conjugated antibodies $(1: 10,000)$ for $1 \mathrm{~h}$. The anti-GAPDH antibodies are used as the loading control $(1: 10,000)$. Immunodetection was performed using chemiluminescent 
substrate Luminata Forte (Merck Millipore) and LAS-3000 imaging system (Fujifilm, Tokyo, Japan). Densitometric analysis of signals was carried out using ImageJ software (version $1.39 \mathrm{o}$, National Institutes of Health, Bethesda, MD, USA). Preliminarily to expression experiments, positive controls samples were used to further validate the banding pattern of each antibody (Figure S2).

\subsection{Immunofluorescence}

HDLECs were plated on $0.1 \%$ gelatin-coated sterile glass coverslips in removable 12 well chambers (Ibidi GmbH, Martinsried, Germany) at $2 \times 10^{4}$ cells/well in EGM-V2. After $48 \mathrm{~h}$, HDLECs were washed with 1X PBS and fixed in 4\% PFA in 1X PBS at room temperature (RT) for $10 \mathrm{~min}$. HDLECs were then washed with 1X PBS and coverslips were blocked with 1\% BSA, 1\% Triton X100 in 1X PBS at RT for $1 \mathrm{~h}$. HDLECs were incubated overnight at $4{ }^{\circ} \mathrm{C}$ with anti-PANX1 primary antibodies prepared in blocking buffer at 1:100 dilution. A negative control was performed by omitting the primary antibody. The following day, HDLECs were incubated with Alexa Fluor 555 donkey anti-goat secondary antibodies (1:500) in blocking buffer for $2 \mathrm{~h}$ at RT. F-actin filaments and cell nuclei were stained with $1 \mathrm{nM}$ FITC-phalloidin (Life Technologies, Thermo Fisher Scientific, Waltham, MA, USA) and $100 \mathrm{nM}$ DAPI (Molecular Probes, Thermo Fisher Scientific) in 1X PBS for $30 \mathrm{~min}$ at RT. After extensive washing with 1X PBS, cover slips were mounted with Mowiol fluorescent mounting medium and Images were captured using a confocal microscope (Olympus FV1000, Tokyo, Japan). Control experiment omitting primary antibody was also performed.

\section{6. siRNA Interference}

The siRNA sequence used for small-interfering RNA-mediated inhibition of PANX1 was the following: PANX1 siRNA: 5'-AGGAUCCCUGAUUUGAUGCTG-3'. The siRNA sequence for the non-targeting control siRNA was undisclosed by the manufacturer. Transfections were performed using siPORT reagent according to the manufacturer's instructions. $2 \times 10^{5}$ HDLECs in $2.3 \mathrm{~mL}$ EGM-V2 medium were seeded in six-well plates. For each well, $5 \mu \mathrm{L}$ siPORT Amine agent were diluted into $100 \mu \mathrm{L}$ Opti-MEM medium and incubated for $10 \mathrm{~min}$ at RT. $7.5 \mu \mathrm{L}$ and $12.5 \mu \mathrm{L}$ of PANX1 or scramble siRNA at 10 and $1 \mu \mathrm{M}$ respectively were diluted into Opti-MEM. Diluted siRNA and diluted siPORT Amine agent were mixed, incubated for $10 \mathrm{~min}$ at RT and finally dispensed onto HDLECs. Medium was finally removed $24 \mathrm{~h}$ after transfection prior experiments. The efficiency of the siRNA knockdown was determined by Western blot analysis 24 and $48 \mathrm{~h}$ post-transfection. XTT assay confirmed non-cytotoxic effects of both siPORT and oligos after $24 \mathrm{~h}$ treatment on HDLECs (Figure S3).

\subsection{Cell Proliferation}

BrdU incorporation assay was used to monitor the mitogenic effects of the siRNA silencing of PANX1. siRNA-transfected HDLECs were plated in 96-well plates at a density of $6 \times 10^{3}$ cells/well in $100 \mu \mathrm{L}$ EGM-V2 and after $24 \mathrm{~h}$ bromodeoxyuridine (BrdU) was added into wells at a final concentration of $100 \mu \mathrm{M}$ and incubated overnight at $37^{\circ} \mathrm{C}$. BrdU incorporation rate was measured using "Cell Proliferation ELISA, BrdU colorimetric kit" (Roche Applied Science, Penzberg, Germany) according to the manufacturer's instructions. Absorbance was measured at $450 \mathrm{~nm}$ with a 96 -well microplate reader after adding sulfuric acid to stop colorimetric reaction.

\subsection{Tube Formation}

96-well plates were coated with $50 \mu \mathrm{L} /$ well of cold Matrigel and allowed to solidify for $1 \mathrm{~h}$ at $37^{\circ} \mathrm{C}$. HDLECs were trypsinized and $15 \times 10^{3}$ cells in $200 \mu \mathrm{L}$ of EGM-V2 medium were loaded on the solidified Matrigel in the presence or absence of PANX1 chemical inhibitors, Probenecid (at 1 or $2 \mathrm{mM}$ final) or BBFCF (at 1 or $5 \mu \mathrm{M}$ final). In a second set of experiments, HDLECs were mixed and loaded on Matrigel with the specific PANX1 mimetic peptide channel blocker, ${ }^{10} \mathrm{Panx}$ or the control peptide at 50 or $100 \mu \mathrm{M}$. Finally, PANX1 or control siRNA-transfected HDLECs were used in the same conditions than the native HDLECs in this assay. After $20 \mathrm{~h}$, HDLECs were stained with $25 \mu \mathrm{M}$ calcein-AM 
and then fixed with $2 \%$ PFA in 1X PBS. The 3-dimensional cell organization was photographed using Olympus MVX10 macroscope (objective $1 \times / 1 ; 22{ }^{\circ} \mathrm{C}$; medium: PBS; Camera: Hamamatsu ORCA-03G; cellSens Dimension Version 1.4 software Olympus, Tokyo, Japan). Capillary-like structures (length of tubule complexes and number of junctions) were quantified by automatic counting in duplicate using the AngioQuant Version 1.33 software. Previously to these experiments we have determined that the concentrations of inhibitors used in this assay on the HDLECs were not cytotoxic (Figure S3).

\subsection{Endothelial Cells Invasion}

HDLECs migration was evaluated using 24-well cell culture inserts with 8 - $\mu$ m pores (BD Biosciences, Franklin Lakes, NJ, USA). $24 \mathrm{~h}$ after siRNA transfection, HDLECs were rinsed with EBM-2 media, detached with trypsin and seeded at $5 \times 10^{4}$ cells $/ 100 \mu \mathrm{L} 0.5 \%$ FCS EBM-2 onto Matrigel-coated $(25 \mu \mathrm{L}$ of $1 \mathrm{mg} / \mathrm{mL}$ ) inserts. The inserts were then placed in the 24-well plates containing $500 \mu \mathrm{L}$ of EBM-2 medium with or without $100 \mathrm{ng} / \mathrm{mL}$ recombinant human VEGF-C. The filters were removed following incubation for $17 \mathrm{~h}$ at $37^{\circ} \mathrm{C}$ and $5 \% \mathrm{CO}_{2}$ and the Matrigel was wiped with a cotton swab. The invasive HDLECs were fixed in $4 \%$ PFA for $10 \mathrm{~min}$ prior to staining with DAPI. Filters were mounted with Mowiol fluorescent mounting medium and cells were photographed using an Olympus MVX10 macroscope (objective 2X, Tokyo, Japan). Cells were counted using ImageJ software after binarizing images.

\subsection{Statistical Analysis}

Statistical analyses were carried out on GraphPad Prism 5 software. All reported data are expressed as mean \pm SD. ANOVA followed by Bonferroni post-tests was performed for analysis of 3 or more groups. Unpaired Student's $t$-test (Mann-Whitney) was used when only 2 experimental groups were analyzed.

\section{Conclusions}

In this study, we provide evidences that Pannexin-1 is expressed in human lymphatic endothelial cells and is involved in in vitro lymphangiogenesis.

Supplementary Materials: Supplementary materials can be found at http://www.mdpi.com/1422-0067/19/6/ 1558/s1.

Author Contributions: Conceptualization, A.M.; Data curation, J.B.; Formal analysis, J.B.; Funding acquisition, M.M., L.C. and A.M.; Investigation, J.B., C.S., G.D., A.-C.B., L.C. and A.M.; Methodology, J.B., C.S., G.D., J.C., A.-C.B. and A.M.; Project administration, A.M.; Resources, M.M., L.C. and A.M.; Supervision, A.M.; Validation, J.B. and J.C.; Visualization, J.B. and A.M.; Writing—original draft, A.M.; Writing—review \& editing, M.M., L.C. and A.M.

Funding: This work was supported by funds from the "Ligue Nationale contre le cancer" (Comités de la Vienne, Deux-Sèvres and Charente-Maritime). J.B. was recipient of a doctoral fellowship from the "Ministère de l'enseignement supérieur et de la recherche".

Acknowledgments: Human primary keratinocytes were a kind gift from F. Morel (LITEC EA 4331, Université de Poitiers, France). We thank Anne Cantereau (ImageUP, University of Poitiers) for technical assistance in confocal microscopy.

Conflicts of Interest: The authors declare no conflict of interest. 


\section{Abbreviations}

$\begin{array}{ll}\text { BrdU } & \text { Bromodeoxyuridine } \\ \text { CX } & \text { Connexin } \\ \text { DAPI } & 4^{\prime} \text {,6-diamidino-2-phenylindole } \\ \text { EBM } & \text { Endothelial cell basal medium } \\ \text { ECs } & \text { Endothelial cells } \\ \text { EGM } & \text { Endothelial cell growth medium } \\ \text { FCS } & \text { Fetal calf serum } \\ \text { GAPDH } & \text { Glyceraldehyde 3-phosphate dehydrogenase } \\ \text { HDLECs } & \text { Human dermal lymphatic endothelial cells } \\ \text { HUVECs } & \text { Human umbilical vein endothelial cells } \\ \text { PANX } & \text { Pannexin } \\ \text { PBS } & \text { Phosphate-buffered saline } \\ \text { PFA } & \text { Paraformaldehyde } \\ \text { RT } & \text { Room temperature } \\ \text { RT-PCR } & \text { Reverse transcription-polymerase chain reaction } \\ \text { siRNA } & \text { Small-interfering RNA } \\ \text { SMCs } & \text { Smooth muscle cells } \\ \text { TBS } & \text { Tris-buffered saline } \\ \text { VEGF-C } & \text { Vascular endothelial growth factor-C }\end{array}$

\section{References}

1. Panchin, Y.; Kelmanson, I.; Matz, M.; Lukyanov, K.; Usman, N.; Lukyanov, S. A ubiquitous family of putative gap junction molecules. Curr. Biol. 2000, 10, R473-R474. [CrossRef]

2. Baranova, A.; Ivanov, D.; Petrash, N.; Pestova, A.; Skoblov, M.; Kelmanson, I.; Shagin, D.; Nazarenko, S.; Geraymovych, E.; Litvin, O.; et al. The mammalian pannexin family is homologous to the invertebrate innexin gap junction proteins. Genomics 2004, 83, 706-716. [CrossRef] [PubMed]

3. Ambrosi, C.; Gassmann, O.; Pranskevich, J.N.; Boassa, D.; Smock, A.; Wang, J.; Dahl, G.; Steinem, C.; Sosinsky, G.E. Pannexin1 and Pannexin2 channels show quaternary similarities to connexons and different oligomerization numbers from each other. J. Biol. Chem. 2010, 285, 24420-24431. [CrossRef] [PubMed]

4. Boassa, D.; Ambrosi, C.; Qiu, F.; Dahl, G.; Gaietta, G.; Sosinsky, G. Pannexin1 channels contain a glycosylation site that targets the hexamer to the plasma membrane. J. Biol. Chem. 2007, 282, 31733-31743. [CrossRef] [PubMed]

5. Sosinsky, G.E.; Boassa, D.; Dermietzel, R.; Duffy, H.S.; Laird, D.W.; MacVicar, B.; Naus, C.C.; Penuela, S.; Scemes, E.; Spray, D.C.; et al. Pannexin channels are not gap junction hemichannels. Channels 2011, 5, $193-197$. [CrossRef] [PubMed]

6. Bao, L.; Locovei, S.; Dahl, G. Pannexin membrane channels are mechanosensitive conduits for ATP. FEBS Lett. 2004, 572, 65-68. [CrossRef] [PubMed]

7. Ma, W.; Compan, V.; Zheng, W.; Martin, E.; North, R.A.; Verkhratsky, A.; Surprenant, A. Pannexin 1 forms an anion-selective channel. Pflugers Arch. 2012, 463, 585-592. [CrossRef] [PubMed]

8. Dvoriantchikova, G.; Ivanov, D.; Panchin, Y.; Shestopalov, V.I. Expression of pannexin family of proteins in the retina. FEBS Lett. 2006, 580, 2178-2182. [CrossRef] [PubMed]

9. Dvoriantchikova, G.; Ivanov, D.; Pestova, A.; Shestopalov, V. Molecular characterization of pannexins in the lens. Mol. Vis. 2006, 12, 1417-1426. [PubMed]

10. Seminario-Vidal, L.; Kreda, S.; Jones, L.; O’Neal, W.; Trejo, J.; Boucher, R.C.; Lazarowski, E.R. Thrombin promotes release of ATP from lung epithelial cells through coordinated activation of rho- and $\mathrm{Ca}^{2+}$-dependent signaling pathways. J. Biol. Chem. 2009, 284, 20638-20648. [CrossRef] [PubMed]

11. Celetti, S.J.; Cowan, K.N.; Penuela, S.; Shao, Q.; Churko, J.; Laird, D.W. Implications of pannexin 1 and pannexin 3 for keratinocyte differentiation. J. Cell Sci. 2010, 123, 1363-1372. [CrossRef] [PubMed]

12. Lohman, A.W.; Billaud, M.; Straub, A.C.; Johnstone, S.R.; Best, A.K.; Lee, M.; Barr, K.; Penuela, S.; Laird, D.W.; Isakson, B.E. Expression of pannexin isoforms in the systemic murine arterial network. J. Vasc. Res. 2012, 49, 405-416. [CrossRef] [PubMed] 
13. Bruzzone, R.; Hormuzdi, S.G.; Barbe, M.T.; Herb, A.; Monyer, H. Pannexins, a family of gap junction proteins expressed in brain. Proc. Natl. Acad. Sci. USA 2003, 100, 13644-13649. [CrossRef] [PubMed]

14. Le Vasseur, M.; Lelowski, J.; Bechberger, J.F.; Sin, W.-C.; Naus, C.C. Pannexin 2 protein expression is not restricted to the CNS. Front. Cell. Neurosci. 2014, 8, 392. [CrossRef] [PubMed]

15. Penuela, S.; Bhalla, R.; Gong, X.-Q.; Cowan, K.N.; Celetti, S.J.; Cowan, B.J.; Bai, D.; Shao, Q.; Laird, D.W. Pannexin 1 and pannexin 3 are glycoproteins that exhibit many distinct characteristics from the connexin family of gap junction proteins. J. Cell Sci. 2007, 120, 3772-3783. [CrossRef] [PubMed]

16. Iwamoto, T.; Nakamura, T.; Doyle, A.; Ishikawa, M.; de Vega, S.; Fukumoto, S.; Yamada, Y. Pannexin 3 regulates intracellular ATP/cAMP levels and promotes chondrocyte differentiation. J. Biol. Chem. 2010, 285, 18948-18958. [CrossRef] [PubMed]

17. Bond, S.R.; Lau, A.; Penuela, S.; Sampaio, A.V.; Underhill, T.M.; Laird, D.W.; Naus, C.C. Pannexin 3 is a novel target for Runx2, expressed by osteoblasts and mature growth plate chondrocytes. J. Bone Miner. Res. 2011, 26, 2911-2922. [CrossRef] [PubMed]

18. Cowan, K.N.; Langlois, S.; Penuela, S.; Cowan, B.J.; Laird, D.W. Pannexin1 and Pannexin3 exhibit distinct localization patterns in human skin appendages and are regulated during keratinocyte differentiation and carcinogenesis. Cell Commun. Adhes. 2012, 19, 45-53. [CrossRef] [PubMed]

19. Oh, S.-K.; Shin, J.-O.; Baek, J.-I.; Lee, J.; Bae, J.W.; Ankamerddy, H.; Kim, M.-J.; Huh, T.-L.; Ryoo, Z.-Y.; Kim, U.-K.; et al. Pannexin 3 is required for normal progression of skeletal development in vertebrates. FASEB J. 2015, 29, 4473-4484. [CrossRef] [PubMed]

20. Caskenette, D.; Penuela, S.; Lee, V.; Barr, K.; Beier, F.; Laird, D.W.; Willmore, K.E. Global deletion of Panx3 produces multiple phenotypic effects in mouse humeri and femora. J. Anat. 2016, 228, 746-756. [CrossRef] [PubMed]

21. Ishikawa, M.; Yamada, Y. The Role of Pannexin 3 in Bone Biology. J. Dent. Res. 2017, 96, 372-379. [CrossRef] [PubMed]

22. Wang, X.-H.; Streeter, M.; Liu, Y.-P.; Zhao, H.-B. Identification and characterization of pannexin expression in the mammalian cochlea. J. Comp. Neurol. 2009, 512, 336-346. [CrossRef] [PubMed]

23. Langlois, S.; Xiang, X.; Young, K.; Cowan, B.J.; Penuela, S.; Cowan, K.N. Pannexin 1 and pannexin 3 channels regulate skeletal muscle myoblast proliferation and differentiation. J. Biol. Chem. 2014, 289, 30717-30731. [CrossRef] [PubMed]

24. Gulbransen, B.D.; Bashashati, M.; Hirota, S.A.; Gui, X.; Roberts, J.A.; MacDonald, J.A.; Muruve, D.A.; McKay, D.M.; Beck, P.L.; Mawe, G.M.; et al. Activation of neuronal P2X7 receptor-pannexin-1 mediates death of enteric neurons during colitis. Nat. Med. 2012, 18, 600-604. [CrossRef] [PubMed]

25. Penuela, S.; Gyenis, L.; Ablack, A.; Churko, J.M.; Berger, A.C.; Litchfield, D.W.; Lewis, J.D.; Laird, D.W. Loss of pannexin 1 attenuates melanoma progression by reversion to a melanocytic phenotype. J. Biol. Chem. 2012, 287, 29184-29193. [CrossRef] [PubMed]

26. Furlow, P.W.; Zhang, S.; Soong, T.D.; Halberg, N.; Goodarzi, H.; Mangrum, C.; Wu, Y.G.; Elemento, O.; Tavazoie, S.F. Mechanosensitive pannexin-1 channels mediate microvascular metastatic cell survival. Nat. Cell Biol. 2015, 17, 943-952. [CrossRef] [PubMed]

27. Billaud, M.; Lohman, A.W.; Straub, A.C.; Looft-Wilson, R.; Johnstone, S.R.; Araj, C.A.; Best, A.K.; Chekeni, F.B.; Ravichandran, K.S.; Penuela, S.; et al. Pannexin1 regulates $\alpha 1$-adrenergic receptor-mediated vasoconstriction. Circ. Res. 2011, 109, 80-85. [CrossRef] [PubMed]

28. Lohman, A.W.; Weaver, J.L.; Billaud, M.; Sandilos, J.K.; Griffiths, R.; Straub, A.C.; Penuela, S.; Leitinger, N.; Laird, D.W.; Bayliss, D.A.; et al. S-nitrosylation inhibits pannexin 1 channel function. J. Biol. Chem. 2012, 287, 39602-39612. [CrossRef] [PubMed]

29. Gödecke, S.; Roderigo, C.; Rose, C.R.; Rauch, B.H.; Gödecke, A.; Schrader, J. Thrombin-induced ATP release from human umbilical vein endothelial cells. Am. J. Physiol.-Cell Physiol. 2012, 302, C915-C923. [CrossRef] [PubMed]

30. Lohman, A.W.; Leskov, I.L.; Butcher, J.T.; Johnstone, S.R.; Stokes, T.A.; Begandt, D.; DeLalio, L.J.; Best, A.K.; Penuela, S.; Leitinger, N.; et al. Pannexin 1 channels regulate leukocyte emigration through the venous endothelium during acute inflammation. Nat. Commun. 2015, 6, 7965. [CrossRef] [PubMed]

31. Gaynullina, D.; Tarasova, O.S.; Kiryukhina, O.O.; Shestopalov, V.I.; Panchin, Y. Endothelial function is impaired in conduit arteries of pannexin1 knockout mice. Biol. Direct 2014, 9, 8. [CrossRef] [PubMed] 
32. Bargiotas, P.; Krenz, A.; Hormuzdi, S.G.; Ridder, D.A.; Herb, A.; Barakat, W.; Penuela, S.; von Engelhardt, J.; Monyer, H.; Schwaninger, M. Pannexins in ischemia-induced neurodegeneration. Proc. Natl. Acad. Sci. USA 2011, 108, 20772-20777. [CrossRef] [PubMed]

33. Billaud, M.; Sandilos, J.K.; Isakson, B.E. Pannexin 1 in the regulation of vascular tone. Trends Cardiovasc. Med. 2012, 22, 68-72. [CrossRef] [PubMed]

34. Good, M.E.; Begandt, D.; DeLalio, L.J.; Keller, A.S.; Billaud, M.; Isakson, B.E. Emerging concepts regarding pannexin 1 in the vasculature. Biochem. Soc. Trans. 2015, 43, 495-501. [CrossRef] [PubMed]

35. Escobedo, N.; Oliver, G. Lymphangiogenesis: Origin, Specification, and Cell Fate Determination. Annu. Rev. Cell Dev. Biol. 2016, 32, 677-691. [CrossRef] [PubMed]

36. Sabin, F.R. On the origin of the lymphatic system from the veins and the development of the lymph hearts and thoracic duct in the pig. Am. J. Anat. 1902, 1, 367-389. [CrossRef]

37. Yang, Y.; Oliver, G. Development of the mammalian lymphatic vasculature. J. Clin. Investig. 2014, 124, 888-897. [CrossRef] [PubMed]

38. Venero Galanternik, M.; Stratman, A.N.; Jung, H.M.; Butler, M.G.; Weinstein, B.M. Building the drains: The lymphatic vasculature in health and disease. Wiley Interdiscip. Rev. Dev. Biol. 2016, 5, 689-710. [CrossRef] [PubMed]

39. Jeltsch, M.; Kaipainen, A.; Joukov, V.; Meng, X.; Lakso, M.; Rauvala, H.; Swartz, M.; Fukumura, D.; Jain, R.K.; Alitalo, K. Hyperplasia of lymphatic vessels in VEGF-C transgenic mice. Science 1997, 276, 1423-1425. [CrossRef] [PubMed]

40. Kanady, J.D.; Dellinger, M.T.; Munger, S.J.; Witte, M.H.; Simon, A.M. Connexin37 and Connexin43 deficiencies in mice disrupt lymphatic valve development and result in lymphatic disorders including lymphedema and chylothorax. Dev. Biol. 2011, 354, 253-266. [CrossRef] [PubMed]

41. Sabine, A.; Agalarov, Y.; Maby-El Hajjami, H.; Jaquet, M.; Hägerling, R.; Pollmann, C.; Bebber, D.; Pfenniger, A.; Miura, N.; Dormond, O.; et al. Mechanotransduction, PROX1, and FOXC2 cooperate to control connexin37 and calcineurin during lymphatic-valve formation. Dev. Cell 2012, 22, 430-445. [CrossRef] [PubMed]

42. Munger, S.J.; Kanady, J.D.; Simon, A.M. Absence of venous valves in mice lacking Connexin37. Dev. Biol. 2013, 373, 338-348. [CrossRef] [PubMed]

43. Ferrell, R.E.; Baty, C.J.; Kimak, M.A.; Karlsson, J.M.; Lawrence, E.C.; Franke-Snyder, M.; Meriney, S.D.; Feingold, E.; Finegold, D.N. GJC2 missense mutations cause human lymphedema. Am. J. Hum. Genet. 2010, 86, 943-948. [CrossRef] [PubMed]

44. Ostergaard, P.; Simpson, M.A.; Brice, G.; Mansour, S.; Connell, F.C.; Onoufriadis, A.; Child, A.H.; Hwang, J.; Kalidas, K.; Mortimer, P.S.; et al. Rapid identification of mutations in GJC2 in primary lymphoedema using whole exome sequencing combined with linkage analysis with delineation of the phenotype. J. Med. Genet. 2011, 48, 251-255. [CrossRef] [PubMed]

45. Molica, F.; Meens, M.J.; Dubrot, J.; Ehrlich, A.; Roth, C.L.; Morel, S.; Pelli, G.; Vinet, L.; Braunersreuther, V.; Ratib, O.; et al. Pannexin1 links lymphatic function to lipid metabolism and atherosclerosis. Sci. Rep. 2017, 7, 13706. [CrossRef] [PubMed]

46. Penuela, S.; Bhalla, R.; Nag, K.; Laird, D.W. Glycosylation regulates pannexin intermixing and cellular localization. Mol. Biol. Cell 2009, 20, 4313-4323. [CrossRef] [PubMed]

47. Penuela, S.; Gehi, R.; Laird, D.W. The biochemistry and function of pannexin channels. Biochim. Biophys. Acta 2013, 1828, 15-22. [CrossRef] [PubMed]

48. Shestopalov, V.I.; Panchin, Y. Pannexins and gap junction protein diversity. Cell. Mol. Life Sci. 2008, 65, 376-394. [CrossRef] [PubMed]

49. Penuela, S.; Celetti, S.J.; Bhalla, R.; Shao, Q.; Laird, D.W. Diverse Subcellular Distribution Profiles of Pannexin1 and Pannexin3. Cell Commun. Adhes. 2008, 15, 133-142. [CrossRef] [PubMed]

50. Bhalla-Gehi, R.; Penuela, S.; Churko, J.M.; Shao, Q.; Laird, D.W. Pannexin1 and pannexin3 delivery, cell surface dynamics, and cytoskeletal interactions. J. Biol. Chem. 2010, 285, 9147-9160. [CrossRef] [PubMed]

51. Zappalà, A.; Cicero, D.; Serapide, M.F.; Paz, C.; Catania, M.V.; Falchi, M.; Parenti, R.; Pantò, M.R.; La Delia, F.; Cicirata, F. Expression of pannexin1 in the CNS of adult mouse: Cellular localization and effect of 4-aminopyridine-induced seizures. Neuroscience 2006, 141, 167-178. [CrossRef] [PubMed]

52. Huang, Y.; Grinspan, J.B.; Abrams, C.K.; Scherer, S.S. Pannexin1 is expressed by neurons and glia but does not form functional gap junctions. Glia 2007, 55, 46-56. [CrossRef] [PubMed] 
53. Boassa, D.; Nguyen, P.; Hu, J.; Ellisman, M.H.; Sosinsky, G.E. Pannexin2 oligomers localize in the membranes of endosomal vesicles in mammalian cells while Pannexin1 channels traffic to the plasma membrane. Front. Cell. Neurosci. 2014, 8, 468. [CrossRef] [PubMed]

54. Boyce, A.K.J.; Epp, A.L.; Nagarajan, A.; Swayne, L.A. Transcriptional and post-translational regulation of pannexins. Biochim. Biophys. Acta 2018, 1860, 72-82. [CrossRef] [PubMed]

55. Vanden Abeele, F.; Bidaux, G.; Gordienko, D.; Beck, B.; Panchin, Y.V.; Baranova, A.V.; Ivanov, D.V.; Skryma, R.; Prevarskaya, N. Functional implications of calcium permeability of the channel formed by pannexin 1 . J. Cell Biol. 2006, 174, 535-546. [CrossRef] [PubMed]

56. Anselmi, F.; Hernandez, V.H.; Crispino, G.; Seydel, A.; Ortolano, S.; Roper, S.D.; Kessaris, N.; Richardson, W.; Rickheit, G.; Filippov, M.A.; et al. ATP release through connexin hemichannels and gap junction transfer of second messengers propagate $\mathrm{Ca}^{2+}$ signals across the inner ear. Proc. Natl. Acad. Sci. USA 2008, 105, 18770-18775. [CrossRef] [PubMed]

57. Qu, Y.; Misaghi, S.; Newton, K.; Gilmour, L.L.; Louie, S.; Cupp, J.E.; Dubyak, G.R.; Hackos, D.; Dixit, V.M. Pannexin-1 Is Required for ATP Release during Apoptosis but Not for Inflammasome Activation. J. Immunol. 2011, 186, 6553-6561. [CrossRef] [PubMed]

58. Shao, Q.; Lindstrom, K.; Shi, R.; Kelly, J.; Schroeder, A.; Juusola, J.; Levine, K.L.; Esseltine, J.L.; Penuela, S.; Jackson, M.F.; et al. A Germline Variant in the PANX1 Gene Has Reduced Channel Function and Is Associated with Multisystem Dysfunction. J. Biol. Chem. 2016, 291, 12432-12443. [CrossRef] [PubMed]

59. Lohman, A.W.; Isakson, B.E. Differentiating connexin hemichannels and pannexin channels in cellular ATP release. FEBS Lett. 2014, 588, 1379-1388. [CrossRef] [PubMed]

60. Ishikawa, M.; Iwamoto, T.; Nakamura, T.; Doyle, A.; Fukumoto, S.; Yamada, Y. Pannexin 3 functions as an $\mathrm{ER} \mathrm{Ca}^{2+}$ channel, hemichannel, and gap junction to promote osteoblast differentiation. J. Cell Biol. 2011, 193, 1257-1274. [CrossRef] [PubMed]

61. Wicki-Stordeur, L.E.; Dzugalo, A.D.; Swansburg, R.M.; Suits, J.M.; Swayne, L.A. Pannexin 1 regulates postnatal neural stem and progenitor cell proliferation. Neural Dev. 2012, 7, 11. [CrossRef] [PubMed]

62. Wei, L.; Yang, X.; Shi, X.; Chen, Y. Pannexin-1 silencing inhibits the proliferation of U87-MG cells. Mol. Med. Rep. 2015, 11, 3487-3492. [CrossRef] [PubMed]

63. Alvarez, A.; Lagos-Cabré, R.; Kong, M.; Cárdenas, A.; Burgos-Bravo, F.; Schneider, P.; Quest, A.F.G.; Leyton, L. Integrin-mediated transactivation of P2X7R via hemichannel-dependent ATP release stimulates astrocyte migration. Biochim. Biophys. Acta 2016, 1863, 2175-2188. [CrossRef] [PubMed]

64. Sáez, P.J.; Vargas, P.; Shoji, K.F.; Harcha, P.A.; Lennon-Duménil, A.-M.; Sáez, J.C. ATP promotes the fast migration of dendritic cells through the activity of pannexin 1 channels and P2X7 receptors. Sci. Signal. 2017, 10, eaah7107. [CrossRef] [PubMed]

65. Yoon, C.M.; Hong, B.S.; Moon, H.G.; Lim, S.; Suh, P.-G.; Kim, Y.-K.; Chae, C.-B.; Gho, Y.S. Sphingosine-1-phosphate promotes lymphangiogenesis by stimulating S1P1/ $\mathrm{G}_{\mathrm{i}} / \mathrm{PLC} / \mathrm{Ca}^{2+}$ signaling pathways. Blood 2008, 112, 1129-1138. [CrossRef] [PubMed]

66. Choi, D.; Park, E.; Jung, E.; Seong, Y.J.; Yoo, J.; Lee, E.; Hong, M.; Lee, S.; Ishida, H.; Burford, J.; et al. Laminar flow downregulates Notch activity to promote lymphatic sprouting. J. Clin. Investig. 2017, 127, 1225-1240. [CrossRef] [PubMed]

67. Niimi, K.; Ueda, M.; Fukumoto, M.; Kohara, M.; Sawano, T.; Tsuchihashi, R.; Shibata, S.; Inagaki, S.; Furuyama, T. Transcription factor FOXO1 promotes cell migration toward exogenous ATP via controlling P2Y1 receptor expression in lymphatic endothelial cells. Biochem. Biophys. Res. Commun. 2017, 489, 413-419. [CrossRef] [PubMed]

68. Bao, B.A.; Lai, C.P.; Naus, C.C.; Morgan, J.R. Pannexin1 drives multicellular aggregate compaction via a signaling cascade that remodels the actin cytoskeleton. J. Biol. Chem. 2012, 287, 8407-8416. [CrossRef] [PubMed]

69. Boyce, A.K.J.; Wicki-Stordeur, L.E.; Swayne, L.A. Powerful partnership: Crosstalk between pannexin 1 and the cytoskeleton. Front. Physiol. 2014, 5, 27. [CrossRef] [PubMed]

(C) 2018 by the authors. Licensee MDPI, Basel, Switzerland. This article is an open access article distributed under the terms and conditions of the Creative Commons Attribution (CC BY) license (http:/ / creativecommons.org/licenses/by/4.0/). 